\title{
PENANAMAN ASPEK SOSIAL EMOSIONAL DALAM PEMBELAJARAN SENTRA DI MASA PEMBELAJARAN JARAK
}

\author{
JAUH \\ Putri Wimbi Tria Rizky ${ }^{1}$, Putri Aulia Diani ${ }^{2}$ \\ ${ }^{1,2}$ Program Studi Pendidikan Guru Pendidikan Anak UsiaDini; Fakultas Psikologi dan Pendidikan; \\ Universitas Al Azhar Indonesia, Jalan Sisingamangaraja Kompleks Masjid Agung Al-Azhar, \\ Kebayoran Jakarta Selatan 12110 \\ Penulis untuk korespondensi/ E-mail: putriwimbi25@gmail.com
}

\begin{abstract}
Abstrak-Penelitian ini bertujuan untuk mengetahui penanaman sosial emosional dalam pembelajaran model sentra di TK Ketilang Jakarta. Metode yang digunakan adalah metode kualitatif dengan pendekatan deskriptif kualitatif.Teknik utama dalam pengambilan data yaitu dengan observasi, wawancara dan dokumentasi. Analisis data pada penelitian ini mengunakan model Milles and Hubberman yang terdiri dari tahap reduksi data, penyajian data dan penarikan kesimpulan. Subjek penelitianini adalah guru kelompok B padakelas B4 TK Ketilang Jakarta. Hasil penelitian menunjukkan bahwa pada pembelajaran jarak jauh dengan menggunakan model pembelajaran sentra terdapat perubahan dalam sistem belajar yaitu dengan hanya menerapkan 1 (satu) sentra dalam satu hari. Perkembangan sosial emosional terkendala karena kurangnya sosialisasi dan interaksi anak dengan teman dan guru sehingga anak cepat marah dan merasa malu saat pembelajaran. Penanaman kemampuan sosial emosional dilakukan dengan cara mengadakan interaksi antara guru dan anak melalui home visit 1 bulan sekali; meminta anak untuk melakukan kegiatan interaksi bersama ayah, ibu, kakak, adik, seperti membersihkan rumah, memasak hingga berkebun; memperkenalkan anak dengan teman-temannya yang dilakukan saat pembelajaran berlangsung, serta mengajak anak-anak memberikan tepuk tangan bila temannya berhasil mengerjakan atau menjawab sesuatu. Media yang digunakan untuk menanamkan kemampuan sosial emosional adalah video pembelajaran.
\end{abstract}

Kata kunci: Anak Usia Dini; Sosial Emosional; Pembelajaran Jarak Jauh

Abstract - This study aims to determine the socio-emotional cultivation in the learning center model at TK Ketilang Jakarta. The method used is a qualitative method with a qualitative descriptive approach. The main techniques in data collection are observation, interviews and documentation. Data analysis in this study used the Milles and Hubberman model which consisted of data reduction, data presentation and conclusion drawing. The subject of this research is the teacher of group B in class B4 TK Ketilang Jakarta. The results showed that in distance learning using the learning center model there was a change in the learning system, namely by only applying 1 (one) center in one day. Socialemotional development is constrained due to the lack of socialization and interaction of children with friends and teachers so that children get angry quickly and feel embarrassed when learning. The inculcation of emotional social skills is carried out by holding interactions between teachers and children through home visits once a month; asking children to do interaction activities with father, mother, brother, sister, such as cleaning the house, cooking to gardening; introduce children to their friends which is done during learning, and invites children to give applause when their friends succeed in doing or answering something. The media used to instill social emotional skills are learning videos

Keywords: Early childhood; Social Emotional; Distance learning 


\section{PENDAHULUAN}

$\mathrm{D}$ unia saat ini tengah menghadapi pandemi Covid-19 atau Corona Virus Disease-2019 yang telah terjadi sejak awal tahun 2020 di Indonesia. Menurut WHO (2020) Covid-19 adalah penyakit menular yang disebabkan oleh jenis coronavirus yang baru ditemukan. Penyebaran Covid-19 yang dapat menular melalui kontak langsung dengan seseorang melalui percikan-percikan dari hidung atau mulut yang keluar saat orang yang terinfeksi Covid-19 batuk, bersin atau berbicara menyebabkan pemerintah menghimbau untuk menerapkan social distancing. Hal ini memberikan dampak bagi dunia pendidikan. Semua pelaksanaan pembelajaran dilakukan di rumah masing-masing melalui daring atau pembelajaran jarak jauh (PJJ).

PJJ dilaksanakan atas instruksi pemerintah agar segala tingkat pendidikan di Indonesia saat ini belajar dari rumah masing-masing. Menurut Prawiyogi et al., (2020), PJJ merupakan pelatihan yang diberikan kepada peserta atau siswa yang tidak berkumpul bersama di suatu tempat secara rutin untuk menerima pelajaran secara langsung dari instruktur. Perubahan yang terjadi adalah sistem pembelajaran tidak diperbolehkan tatap muka secara langsung di sekolah baik perguruan tinggi hingga pendidikan anak usia dini.

Lembaga pendidikan anak usia dini merupakan wadah pendidikan yang diharapkan dapat mengembangkan, membimbing, menstimulasi, mengasah segala aspek yang terdapat pada anak secara optimal.Di dalam pengelolaannya, lembaga dapat menggunakan model pembelajaran sentra, area, atau kelompok.Model pembelajaran sentra atau Beyond Centers and Circle Time (BCCT) merupakan metode pembelajaran yang sering disebut SELI atau Sentra dan Lingkaran. Kegiatan bermain dengan model pembelajaran sentra yang menitikberatkan seluruh kegiatan pembelajarannya pada anak sebagai subyek pembelajaran, sedangkan pendidik lebih banyak berperan sebagai motivator dan fasilitator (Oktaria \& Putra, 2020). Pembelajaran sentra (Beyond Centers and Circle Time)/ BCCT merupakan kegiatan main anak-anak yang terpusat dan anak-anak secara bebas beraktivitas serta mengembangkan berbagai potensi yang dimiliki (Rusman, 2013). Dapat disimpulkan bahwa pembelajaran sentra adalah pembelajaran yang berpusat atau menitikberatkan pada anak, sedangkan guru hanya menjadi motivator dan fasilitator demi mengembangkan potensi-potensi yang dimiliki anak.

Namun, lembaga pendidikan yang menggunakan model pembelajaran sentra atau BCCT merasa sedikit kesulitan karena keterbatasan pembelajaran jarak jauh dalam menstimulasi aspek perkembangan anak yang biasanya dilakukan secara langsung. Kendala yang dialami oleh guru saat masa pandemic Covid-19 adalah dalam mengembangkan salah satu aspek anak yaitu aspek perkembangan sosial emosional. Anak usia dini yang dunianya adalah dunia bermain lebih banyak melibatkan interaksi dan tatap muka langsung, kini hanya dilakukan sebatas layar saja. Kemampuan sosial emosional anak di tengah pandemi Covid-19 dirasa berkurang. Casel dalam Mukhlis \& Mbelo (2019) menyebut pembelajaran sosial emosional (social emotional learning) sebagai sebuah proses dimana anak-anak dan orang dewasa memahami dan mengelola emosi, menetapkan dan mencapai tujuan positif, merasakan dan menunjukkan empati untuk orang lain, membangun dan memelihara hubungan positif, dan membuat keputusan yang bertanggung jawab. Menurut Kusuma \& Sutapa, (2020), pembelajaran daring yang diakibatkan oleh adanya covid-19 tentu saja berpengaruh pada perilaku sosial emosional pada anak yaitu anak kurang bersikap kooperatif karena anak jarang bermain bersama, kegiatan bersosialisasi dengan teman terbatasi karena adanya program belajar dari rumah, emosi anak yang terkadang merasa bosan dan sedih, anak merasa rindu teman dan guru, dan anak juga tercatat mengalami kekerasan verbal karena proses belajar yang lazim.

Penelitian terdahulu yang dilakukan oleh Kusuma \& Sutapa, (2020), dengan judul dampak pembelajaran daring terhadap perilaku sosial emosional anak, menunjukan bahwa: (1) anak kurang bersikap kooperatif untuk menyelesaikan tugas-tugas yang diberikan oleh guru, (2) anak kurang bersosialisasi yang mana anak tidak bertemu dengan teman sebaya nya secara langsung, (3) emosi anak yang terkadang 
merasa bosan bila terus menerus berada di rumah, (4) anak merasa rindu dengan teman dan guru, (5) anak mengalami kekerasan verbal karena proses belajar yang tidak lazim yang merupakan bentuk ucapan dari orang tua untuk anak yang bersifat mengancam, menekan hingga menghina secara tidak sengaja. Akan tetapi guru diharapkan tetap dapat memberikan variasi aktivitas dan tugas pembelajaran belajar dari rumah antarsiswa, sesuai minat dan kondisi masing-masing, termasuk mempertimbangkan kesenjangan akses/ fasilitas belajar dari rumah (Kementerian Pendidikan dan Kebudayaan, 2020).

Berdasarkan hal tersebut, penelitian ini dilakukan dengan tujuan untuk mengetahui penanaman social emosional pada anak dalam pembelajaran sentra di masa pembelajaran jarak jauh.

\section{METODE PENELITIAN}

Penelitan ini menggunakan pendekatan kualitatif, yaitu metode penelitian yang bermaksud untuk memahami fenomena tentang apa yang dialami oleh subjek penelitian dengan cara deskripsi dalam bentuk kata-kata bahasa, pada suatu konteks khusus yang alamiah dan dengan memanfaatkan berbagai metode ilmiah (Anggio \& Setiawan, 2018). Pendekatan kuaitatif yang digunakan adalah dengan metode penelitian deskriptif kualitatif. Adapun analisis data yang digunakan dalam penelitian ini adalah mengunakan model Miles and Huberman. Analisis data dalam penelitian kualitatif dilakukan pada saat pengumpulan data berlangsung, dan setelah selesai pengumpulan data dalam periode tertentu(Sukma, 2020). Penggunaan metode ini digunakan untuk mengetahui penanaman sosial-emosional anak usia 5-6 tahun dalampembelajaran model sentra di TK Ketilang Jakarta selama PJJ. Subjek penelitian ini adalah guru kelompok B4 TK Ketilang Jakarta Pisangan - Ciputat Timur, Tangerang Selatan. Data diambil dengan observasi, wawancara dan dokumentasi.

\section{HASIL DAN PEMBAHASAN}

\section{Kegiatan Pembelajaran}

Rangkaian kegiatan PJJ dalam satu hari, yaitu: pembukaan, guru mengajak anak untuk bernyanyi, membaca doa-doa pendek, membaca syahadat dengan arti, surat Al-Fatiha beserta arti dan doa sebelum belajar yang dipimpin oleh satu anak yang dilakukan bergilir setiap harinya. Kemudia anak di minta membaca Muroja'ah secara bergantian dari surat Al-Fil hingga AlBaqarah ayat 1-10. Setiap anak diminta membaca secara bergantian setiap harinya. Setelah Muroja'ah anak-anak panggil secara bergantia untuk membaca huruf hijaiyah yang di share screen oleh guru. Apabila anak dapat membacanya dengan lancar akan mendapat reward berupa pujian dan bintang, tetapi pada anak yang belum lancar membaca guru tetap memberikan reward berupa bintang dan motivasi agar anak lebih baik lagi.

Kemudian dilanjutkan dengan kegiatan inti, anak melakukan kegiatan sains yaitu anak melakukan eksperimen mencairkan es batu dengan 3 wadah yang masing masing berisi air dingin, air hangat, dan air panas. Anak diminta memasukan es batu kedalam wadah dan mengamati es batu mana yang mencair terlebih dahulu. Kemudian setelah melakukan kegitan sains anak mengerjakan lembar kerja, yang terdapat 3 bagian yang bertuliskan Solid, Liquid dan Gas. Guru menjelaskan bahwa solid adalah benda padat, liquid adalah benda cair, dan gas adalah benda yang seperti udara atau tidak terlihat. Masing-masing anak diminta untuk menggambarkan masing-masing 3 benda pada setiap bagian.

Dan terakhir ada penutup. Setelah selesai, guru melakukan recalling kegiatan hari ini. Lalu anak membaca doa selesai belajar, doa keluar kelas, doa naik kendaraan darat dan doa masuk rumah.

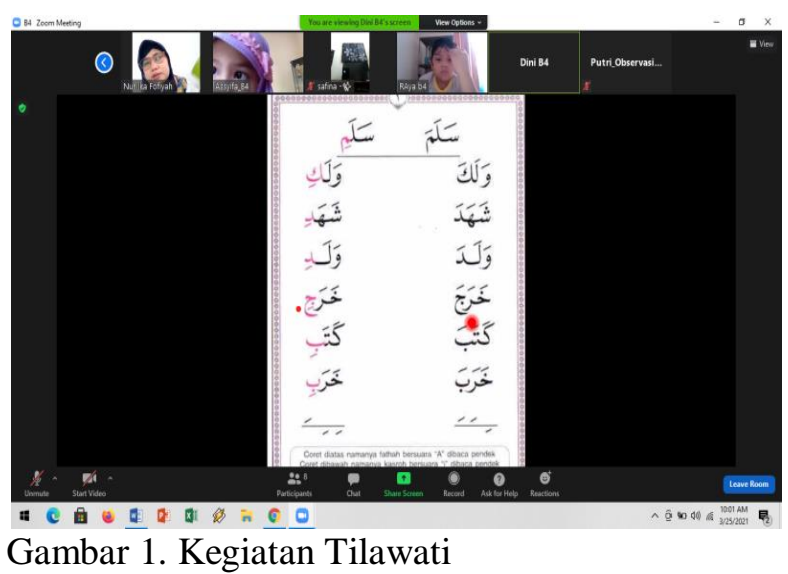




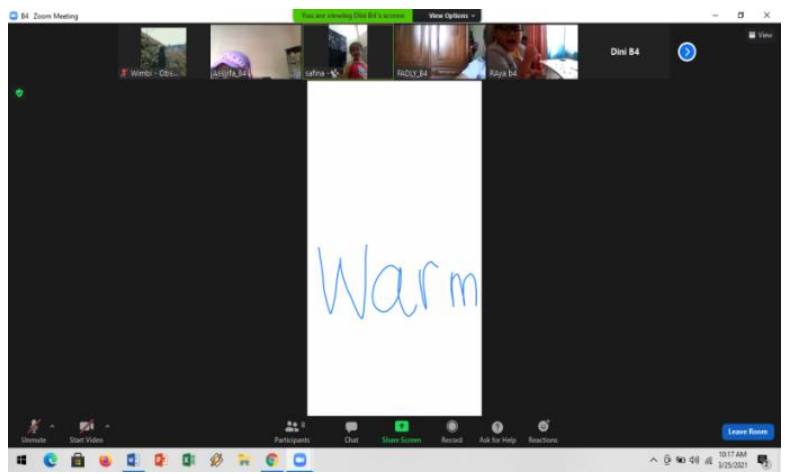

Gambar 2. Pengantar Kegiatan Inti

Strategi pembelajaran yang diterapkan di TK Ketilang adalah student centered. Guru mengajak anak untuk aktif dalam pembelajaran sehari-hari. Guru juga meminta anak melakukan kegiatan tanpa memberitahu hasilnya.

Model pembelajaran sentra pada TK ketilang Jakarta disederhanakan menjadi 1 (satu) sentra dalam satu hari. Pada kegiatan pembelajaran secara langsung (sebelum pandemic), dalam satu hari kegiatan dilakukan 2 (dua) hingga 3 (tiga) sentra. Indikator yang diambil lebih sedikit, interaksi dan juga durasi pembelajaran juga menjadi dipersingkat menjadi 60 (enam puluh) menit. Menurut Suhendro (2020), dalam situasi pandemi ini menjadi tugas seorang pendidik untuk dapat menyiapkan formula strategi pembelajaran agar materi dapat tersampaikan dengan baik. Durasi pembelajaran dipersingkat dan dipadatkan dikarenakan mengadaptasi tingkat fokus anak dalam PJJ. Anak terkadang sulit untuk duduk diam di depan layar untuk waktu yang cukup lama.

Sekolah TK Ketilang Jakarta menggunakan sumber rujukan dari kurikulum pendidikan nasional dan kurikulum dari kementerian agama serta program guide dari Alfa and Friends.

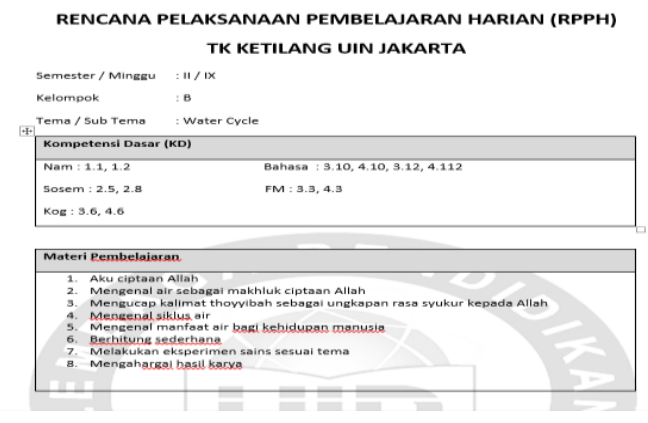

Gambar 3. Rencana Pelaksanaan Pembelajaran Harian (RPPH) Saat PJJ

\begin{tabular}{|c|c|c|}
\hline \multirow{2}{*}{ 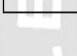 } & \multirow{2}{*}{ 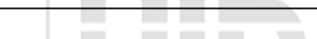 } & 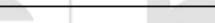 \\
\hline & & 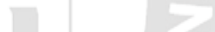 \\
\hline \multicolumn{3}{|c|}{ Kegiatan Main di Kegiatan Inti dan Alat Bahan } \\
\hline Waktu & Kegiatan Main & Alat dan Bahan \\
\hline \multirow{2}{*}{ Senia } & 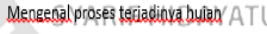 & Poster, flash card, gambar \\
\hline & Alfa and Friends workbook page 22 $\mid A$ & Buku alfa dan alat tuliš \\
\hline Selasa & Kegiatan foto toga kelompok B & 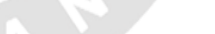 \\
\hline \multirow{2}{*}{ Rabu } & Olabraga bersama & video \\
\hline & Mengrambar Becsama Kak Suori & Kertas gambar dan krayen \\
\hline \multirow{2}{*}{ Kamis } & $\begin{array}{l}\text { Science Eksperimen "Bagaimana Air } \\
\text { Menguag?" }\end{array}$ & $\begin{array}{l}\text { Cup foil, tususk sate, air, garam, } \\
\text { dan lilin }\end{array}$ \\
\hline & Alfa and Friends workbook page 21 & Buku alfa dan alat tulis. \\
\hline lumát & Let's make Watercycle Wheel & Science kit alfa \\
\hline
\end{tabular}

Gambar 4. Lanjutan Rencana Pelaksanaan Pembelajaran Harian (RPPH) Saat PJJ

\section{Media dan Metode Pembelajaran selama PJJ}

Pada saat PJJ ada banyak kendala yang dialami oleh guru maupun anak dan orang tua. Belum terbiasa atau belum adaptasi dengan pandemi pada saat awal PJJ, menyebabkan guru dan orang tua masih mencari strategi dan media yang tepat. Media yang digunakan guru selama PJJ adalah buku, beberapa alat permainan edukatif sesuai tema, dan video pembelajaran. Sementara media yang disediakan oleh Alfa and Friends adalah buku, APE dan juga video pembelajaran. Guru juga membuat lembar kegiatan (LK) untuk anak serta menampilkan video pembelajaran dari media YouTube.

Untuk menarik perhatian anak selama pembelajaran, biasanya guru memberikan anak game menggunakan aplikasi Quizzes. Hasil belajar anak pada saat PJJ dilihat melalui Zoom Meetings, video, foto dan voice note yang dikirim oleh orang tua sertasaat home visit. Guru akan melakukan penilaian harian dan akan dievaluasi saat home visit untuk mempertimbangkan apakah terdapat kemungkinan-kemungkinan anak belum mampu atau terdapat kendala lainnya.

Media yang digunakan guru selama PJJ adalah buku, beberapa alat permainan edukatif sesuai tema, dan video pembelajaran. Media yang di sediakan oleh Alfa and Friends adalah buku, APE dan juga video pembelajaran. Guru juga 
membuat lembar kegiatan (LK) untuk anak serta menampilkan video pembelajaran dari media YouTube. Untuk menarik perhatian anak apabila anak sudah mulai merasa bosan atau tidak fokus selama pembelajaran, biasa nya guru memberikan anak game menggunakan aplikasi Quizzes. Dalam pelaksanaannya pembelajaran daring tentunya tidak dapat terlepas dari peran teknologi. Teknologi dapat mempermudah segala kebutuhan dalam proses belajar mengajar. Sehubungan dengan hal tersebut Buselic M., Tavakcu T., et al dalam Latip (2020) menegaskan bahwa inti dari pelaksaan pembelajaran daring adalah bagaimana cara memilih metode pembelajaran yang tepat dengan dibantu teknologi yang bermaksud menyampaikan materi pembelajaran kepada peserta didik meskipun tidak bertemu dengan tatap muka secara langsung seperti halnya pembelajaran konvensional. Dengan kata lain, media teknologi sangat berperan penting menjadi pengantar informasi atau materi yang ingin disampaikan oleh guru pada pembelajaran jarak jauh.

Metode yang digunakan oleh TK Ketilang Jakarta adalah applied learning. Applied learning adalah penempatan siswa sebagai subjek yang aktif dan mandiri, bertanggung jawab dalam kegiatan pembelajaran. Guru memberikan kebebasan dalam melakukan pengamalan dan penjelasan identifikasi pada suatu pembelajaran. Sehingga dalam pembelajaran guru melibatkan siswa secara aktif dan langsung dalam kegiatan pembelajaran (Warhandika et al., 2020).

Selama PJJ, guru melakukan komunikasi dengan orang tua melalui WhatsApp Group. Sebelum masuk, TK Ketilang Jakarta telah melakukan test evaluasi perkembangan psikologi anak yang mana dapat dilihat tipe anak seperti apa. Mayoritas anak menggunakan otak kanan (tipe tidak bisa diam, cepat bosan, imajinatif). Guru juga mengatur jadwal dengan orang tua yang bekerja, agar pada saat guru home visit tetap bertemu dan berdiskusi dengan orang tua. Selama PJJ orang tua menjadi guru yang mendampingi anak saat melakukan pembelajaran.Mulai dari menyiapkan alat komunikasi, alat kegiatan dan juga media yang akan digunakan untuk pembelajaran.Terkadang guru juga meminta bantuan orang tua untuk mengirim hafalan surat-surat bagi anak yang tidak hadir dalam kelas.

\section{Penanaman Sosial Emosional pada Anak}

Meskipun pembelajaran dilakukan dalam model jarak jauh, aspek-aspek perkembangan anak harus tetap dilakukan secara optimal. Salah satu aspek perkembangan yang dirasa sulit untuk dikembangkan selama PJJ adalah sosial emosional anak, terlebih pada penerapan social distancing atau menjaga jarak dengan orang lain. Menurut guru, rasanya agak sulit untuk mengenalkan anak dengan teman lainnya di dalam kelas mengingat pembelajaran secara online dilakukan sejak awal tahun ajaran baru dimulai. Anak belum mendapatkan kesempatan untuk akrab dengan teman-temannya di kelas kecuali apabila terdapat anak yang pernah berada di kelas yang sama pada saat kelas A. Interaksi antara guru dan anak hanya terjadi saat home visit yaitu 1 bulan sekali. Pengenalananak dengan teman-temannya, dilakukan saat pembelajaran berlangsung dimana guru meminta anak untuk melihat siapa saja temannya yang belum bergabung ke dalam Zoom Meetings dan mengajak anak-anak memberikan tepuk tangan bila temannya berhasil mengerjakan atau menjawab sesuatu.

Sesuai dengan hasil penelitian yang dilakukan oleh Kusuma \& Sutapa (2020), anak kurang bersosialisasi dalam proses pembelajaran di rumah, anak tidak teman sebayanya dan tidak bertemu dengan teman temannya di sekolah sehingga anak mengalami kurangnya bersosialisasi dengan orang sekitar atau teman sebayanya. Perkembangan sosial merupakan per-kembangan tingkah laku pada anak dimana anak diminta untuk menyesuaikan diri dengan aturan yang berlaku dalam lingkungan masyarakat. Dengan kata lain, perkembangan sosial merupakan proses belajar anak dalam menyesuaikan diri dengan norma, moral dan tradisi dalam sebuah kelompok.

Di dalam mengembangkan sosial emosional anak, guru menggunakan media berupa video pembelajaran, guru meminta anak untuk melakukan kegiatan interaksi bersama ayah, ibu, kakak, adik, seperti membersihkan rumah, memasak hingga berkebun. Kendala yang dirasakan dalam menstimulasi aspek sosialemosional adalah saat anak menolak melakukan 
Zoom Meetings. Ada salah satu anak hanya mau mengikuti kelas sebanyak 1 kali dalam seminggu, terdapat juga anak yang merasa malu saat melakukan Zoom Meeting karena merasa teman-teman menatapnya dari layar Zoom Meeting.

Guru melakukan kerjasama dengan orang tua untuk mendapatkan informasi perkembangan sosial emosional anak selama PJJ. Terdapat anak yang cenderung cepat marah selama berada di rumah. Kegiatan anak selama dirumah yang tidak boleh keluar dan tidak lepas dari gadget,dihabiskan untuk bermain gadget bila tidak ada kegiatan yang menarik. Apabila orangtua mengambil gadget yang digunakan anak maka anak akan merasa marah karena bosan. Berdasarkan kendala tersebut, guru mempersilahkan anak untuk datang dan melakukan pembelajaran di sekolah. Kegiatan tersebut dilakukan dalam waktu3 hari dalam 1 minggu dengan tetap mematuhi protokol kesehatan.

Menurut hasil penelitian yang dilakukan oleh Fauziah et al., (2020), saat PJJ berlangsung anak mengalami emosi yang berlebihan seperti marah kepada orang tua. Sikap marah atau emosi berlebihan ini sebenarnya pada pembelajaran tatap muka pun kerap juga terjadi, hanya saja dapat dikontrol mereka dikarenakan dekat dengan guru, ketika anak belajar di rumahanak kerap kali kehilangan kontrol. Hal tersebut merupakan dampak dari rasa bosan yang anak alami selama berada di rumah. Gadget yang dianggap anak sebagai penyalur rasa bosan, ketika diambil oleh orang tua karena dirasa sudah menggunakannya di luar batas anak akan bereaksi marah atau emosi berlebihan.

Anak juga menjadi pemalu. Terdapat anak yang enggan untuk melakukan pembelajaran jarak jauh karena merasa semua teman-temannya di layar menatapnya secara bersamaan. Menurut Fauziah et al., (2020), sikap pemalu ini termasuk gangguan psikoemosional anak, seharusnya secara virtual anak tidak akan menjadi pemalu, sebab sang anak tidak bertemu langsung dengan sang guru maupun temannya. Namun perilaku anak malah menunjukkan sikap pemalu, seolah tidak berani menampilkan wajah di depan kamera. Hal ini dianggap orang tua sebagai hal yang wajar mengingat tidak semua anak mempunyai rasa percaya diri yang sama.
Namun, apabila orang tua dan guru tidak membangkitkan rasa percaya diri anak dikhawatirkan hal ini akan berlarut pada diri anak.

Interaksi antara guru dan anak hanya terjadi saat home visit yaitu 1 bulan sekali. Pengenalan anak dengan teman-temannya, dilakukan saat pembelajaran berlangsung, dimana anak diminta untuk melihat siapa saja temannya yang belum bergabung ke dalam Zoom Meetings dan mengajak anak-anak memberikan tepuk tangan bila teman nya berhasil mengerjakan atau menjawab sesuatu. Dalam mengembangkan sosial emosional anak guru menggunakan media berupa video pembelajaran, guru meminta anak untuk melakukan kegiatan interaksi bersama ayah, ibu, kakak, adik, seperti membersihkan rumah, memasak hingga berkebun. Kendala yang dirasakandalam menstimulasi aspek sosial emosional adalah saat anak menolak melakukan Zoom Meetings. Menurut Kemenbdikbud (2020) sebagaimana guru di seluruh dunia mencoba untuk mengurangi kemungkinan kerugian dalam belajar karena gangguan sekolah, keselamatan dan kesejahteraan siswa (students well-being) harus menjadi hal terpenting untuk dipikirkan. Upaya penyampaian kurikulum secara jarak jauh tidak menciptakan lebih banyak stres dan kecemasan bagi siswa dan keluarganya.

\section{SIMPULAN DAN SARAN}

Covid-19 adalah penyakit menular yang disebabkan oleh jenis corona virus yang baru ditemukan. Penyebaran Covid-19 yang dapat menular melalui kontak langsung menyebabkan dunia saat ini mengalami pandemi Sistem pembelajaran mengalami perubahan termasuk lembaga pendidikan yang menggunakan model pembelajaran sentra. Perubahan sistem pembelajaran di lembaga pendidikan TK Ketilang Jakarta yaitu hanya menerapkan 1 (satu)sentra dalam satu hari saat pembelajaran jarak jauh.Pada pembelajaran langsung, kegiatan sentra biasanya dilakukan 2 (dua) hingga 3 (tiga) sentra dalam 1 (satu) hari. Perubahan sistem pembelajaran juga membuat guru harus mencari cara stimulasi aspek yang tepat agar optimal walaupun hanya sebatas pembelajaran jarak jauh.

Salah satu aspek perkembangan anak yang dirasa sulit oleh guru adalah aspek 
perkembangan sosial emosial. Hal ini dikarenakan instruksi pemerintah untuk melakukan social distancing. Kendala yang dirasakan oleh guru adalah anak tidak dapat bersosialisasi dengan baik dengan teman di kelas, anak menjadi cepat marah atau mempunyai emosi berlebihan dan juga menjadi pemalu. Hal tersebut membuat guru mencari solusi berupa pendekatan dengan anak melalui home visit dan mempersilahkan anak untuk datang ke sekolah dengan mematuhi protokol kesehatan serta berkomunikasi baik dengan orang tua.

Adanpun saran dari penulis dalam kondisi saat ini adalah meningkatkan kreativitas guru untuk menciptakan lingkungan belajar secara PJJ yang dapat meningkatkan aspek sosial emosional, seperti membangun komunikasi antara anak dan temannya melalui kegiatan tanpa tatap muka seperti melakukan video call antara anak dan temannya secara personal untuk menanyakan hal-hal menarik mengenai diri masing-masing anak untuk mengenal satu sama lain dan tetap melanjutkan jalinan kerjasama yang baik dengan pendamping atau orang tua agar dapat mendampingi anak bermain dan belajar selama di rumah demi perkembangan anak yang optimal. Hasil penelitian ini juga diharapkan dapat dijadikan referensi untuk mengevaluasi pelaksanaan PJJ, mengingat pembelajaran daring akan terus berlanjut.

\section{DAFTAR PUSTAKA}

Abdul Latip. (2020). Peran literasi teknologi informasi dan komunikasi pada pembelajaran jarak jauh di masa pandemi Covid-19. EduTeach: Jurnal Edukasi Dan Teknologi Pembelajaran, 1(2), 108-116. https://doi.org/10.37859/eduteach.v1i2.1956

Fauziah, I., Ernita, E., Octavia, D. R., \& Dwiyanti, M. (2020). Analisis gangguan psikososial dan emosional aud Di RA Nurul Iman Medan Belawan selama pembelajaran berbasis daring. Kumara Cendekia, 8(3), 316. https://doi.org/10.20961/kc.v8i3.44282

Kusuma, W. S., \& Sutapa, P. (2020). Dampak pembelajaran daring terhadap perilaku sosial emosional anak. Jurnal Obsesi :
Jurnal Pendidikan Anak Usia Dini, 5(2), 1635-1643.

https://doi.org/10.31004/obsesi.v5i2.940

Mukhlis, A., \& Mbelo, F. H. (2019). Analisis perkembangan sosial emosional anak usia dini pada permainan tradisional. Preschool: Jurnal Perkembangan Dan Pendidikan Anak Usia Dini, 1(1), 1-18. http://ejournal.uin-

malang.ac.id/index.php/preschool/article/vie w/8172/7457

Oktaria, R., \& Putra, P. (2020). Pendidikan anak dalam keluarga sebagai strategi pendidikan anak usia dini saat pandemi covid-19. Jurnal Pesona PAUD, 7(1), 41-51.

Prawiyogi, A. G., Purwanugraha, A., Fakhry, G., \& Firmansyah, M. (2020). Efektifitas pembelajaran jarak jauh terhadap pembelajaran siswa di SDIT Cendekia Purwakarta. Jurnal Pendidikan Dasar, 11(01), 94-101.

Rusman. (2013). Model-model pembelajaran. PT. Grafindo Persada.

Sugiono, S., \& Kuntojo, K. (2016). Pengembangan model permainan pracalistung anak usia dini. JPUD - Jurnal Pendidikan Usia Dini, 10(2), 255-276. https://doi.org/10.21009/jpud.102.04

Suhendro, E. (2020). Strategi Pembelajaran Pendidikan Anak Usia Dini di masa pandemi Covid-19. Golden Age, 5(3), 133140. https://doi.org/10.14421/jga.2020.5305

Sukma, A. S. (2020). Pembentukan karakter berbasis keteladanan guru dan pembiasaan murid SIT Al Biruni Jipang Kota Makassar. Education and Human Development Journal, $\quad 5(1), \quad 91-99$. https://doi.org/10.33086/ehdj.v5i1.1453

Warhandika, F. F., R, D. A., \& Permatasari, D. N. (2020). Pembelajaran berbasis applied learning untuk meningkatkan Bahasa Inggris Mim Pk Kartasura. Buletin Literasi Budaya Sekolah, 2(1), 61-66. https://doi.org/10.23917/blbs.v2i1.11613

Question And Answer About Coronavirus: Https://Www.Who.Int/Indonesia/News/Nov el-Coronavirus/Qa/Qa-For-Public diakses pada tanggal 25 April 2021 pukul 16.32 WIB. 